можуть деталізувати неструктуровані завдання, отримавши досвід управління в умовах невизначеності.

\title{
References
}

1.Fiedler, F.E. (1964) Contingency model of leadership effectiveness. Advances in experimental social psychology. New York, №1. P. 149-190.

2.Fidler, F.E. (1968) Personality and situational determinants of leadership effectiveness. Group dinamics. Research and theory. N. Y.: Harper \& Brothers, P. 137-149.

3.Fiedler, F., Garcia, J. (1987) New Approaches to leadership, cognitive resources and organizational performance. New York: John Wiley and Sons. $240 \mathrm{p}$.

4. Schermerhorn, J.R. Jr. (2011) Introduction to Management $11^{\text {th }}$ edition. New York: John Wiley and Sons.

5.Gold, J., Thorpe, R. \& Mumford, A. (2010) Handbook of leadership and management development. Gower Publishing.

6.Fiedler, F. E. (1967) A theory of leadership effectiveness. New York: McGraw-Hill.

7.Hunt, J. G. (1967) A test of the contingency model in three organizations: Urbana: University of Illinois Press.

8.Reviewed Work: A Theory of Leadership Effectiveness. by Fred E. Fiedler Review by: Ralph N. Campbell Campbell, R. (1968). Administrative Science Quarterly, 13(2), 344-348. doi:10.2307/2391461

Дата подання публікації 20.03.2021 p.

УДК 339.56

Галас Л.І., аспірант

Halas L. Postgraduate student

https://orcid.org/0000-0002-3677-0045

Дзямулич М.I., к.е.н., доцент

Dziamulych M. Candidate of Economic Sciences, Associate Professor https://orcid.org/0000-0003-3714-5062

Шматковська Т.О., к.е.н., доцент

Shmatkovska T. Candidate of Economic Sciences, Associate Professor https://orcid.org/0000-0003-2771-9982

\section{ОСОБЛИВОСТІ ЕКСПОРТНОЇ ДІЯЛЬНОСТІ СІЛЬСЬКОГОСПОДАРСЬКИХ ПІДПРИЕМСТВ В УКРАЇНІ}

\author{
Прикарпатський наиіональний університет імені Василя Стефаника \\ Луиький національний технічний університет \\ Волинський національний університет імені Лесі Українки
}

\begin{abstract}
Специфіка сучасного етапу розвитку агросектору в Україні значною мірою залежить від ефективності діяльності національних сільськогосподарських виробників на зовнішніх ринках. Зокрема, особливого значення в аспекті євроінтеграції та відкриття нових ринків для українських підприємств набуває підвищення їх експортної активності у сфері збуту продукції агропромислового комплексу. При цьому важливим компонентом забезпечення такої ефективності є об'єктивна потреба в досягненні належного рівня конкурентоспроможності національних підприємств на зовнішніх ринках, яка дозволить їм переорієнтуватися 3 операцій по збуту сільськогосподарської сировини на торгівлю продуктами переробного комплексу аграрного сектору. Розширення торгівлі продукцією переробного комплексу сприятиме не лише загальному зростанню прибутковості сільськогосподарських виробників від експортних операцій, але й дозволить їм здійснювати діяльністю по розширенню уже наявних ринків збуту завдяки збільшенню пропозиції за товарними групами.

В статті розглянуто сучасні особливості експортної діяльності сільськогосподарських підприємств України в умовах виходу на нові ринки в аспекті економічної глобалізації. Визначено, що забезпечення підвищення ефективності експортної діяльності підприємств агросектору повинне передбачати застосування системи всебічного аналізу та планування специфіки експортних операцій 3 врахуванням конкретних ринкових умов та вимог. При цьому головною метою підприємств повинна залишатися орієнтацію на нарощення обсягів збуту як сільськогосподарської сировини, так і продукції переробної сфери на зовнішніх ринках. Головним аспектом такого підходу повинне бути забезпечення стабільного збільшення частки продукції переробних аграрних виробництв в загальній структурі
\end{abstract}


експорту національних сільськогосподарських виробників. При цьому необхідно сформувати диференційований підхід щодо визначення структури експорту для підприємств агросектору, що потребує запровадження елементів державного регулювання структури сільськогосподарського виробництва задля забезпечення не лише експортних інтересів виробників, але й для запобігання диспропорціям в забезпеченні національного ринку продукцією сільського господарства.

Ключові слова: сільськогосподарські підприємства, експорт, зовнішньоекономічна діяльність, конкурентоспроможність, ефективність експортної діяльності.

\title{
PECULIARITIES OF EXPORT ACTIVITIES OF AGRICULTURAL ENTERPRISES IN UKRAINE
}

\author{
Vasyl Stefanyk Precarpathian National University \\ Lutsk National Technical University \\ Lesya Ukrainka Eastern European National University
}

\begin{abstract}
The specificity of the current stage of development of the agricultural sector in Ukraine largely depends on the efficiency of national agricultural producers in foreign markets. In particular, in terms of European integration and opening of new markets for Ukrainian enterprises, the increase of their export activity in the field of sales of agro-industrial products acquires special significance. An important component of ensuring such efficiency is the objective need to achieve an appropriate level of competitiveness of national enterprises in foreign markets, which will allow them to shift from sales of agricultural raw materials to trade in products of the processing sector of the agricultural sector. The expansion of trade in the products of the processing complex will not only contribute to the overall growth of profitability of agricultural producers from export operations, but also allow them to expand existing markets by increasing the supply of product groups.

The article considers modern features of export activity of agricultural enterprises of Ukraine in the conditions of entering new markets in the aspect of economic globalization. It is determined that ensuring the efficiency of export activity of agricultural enterprises should provide for the application of a system of comprehensive analysis and planning of the specifics of export operations, taking into account specific market conditions and requirements. At the same time, the main goal of enterprises should remain to focus on increasing sales of both agricultural raw materials and processed products in foreign markets. The main aspect of this approach should be to ensure a stable increase in the share of processed agricultural products in the overall export structure of national agricultural producers. It is necessary to form a differentiated approach to determining the structure of exports for agricultural enterprises, which requires the introduction of elements of state regulation of agricultural production to ensure not only the export interests of producers but also to prevent imbalances in the national market of agricultural products.
\end{abstract}

Keywords: agricultural enterprises, exports, foreign economic activity, competitiveness, efficiency of export activity.

Постановка проблеми у загальному вигляді та їі зв'язок 3 важливими науковими та практичними завданнями. Сучасний стан та специфічні умови функціонування сільськогосподарських підприємств в Україні в даний час передбачають необхідність їх адаптації до нових умов в аспекті процесу трансформації відносин у сфері посилення експортної орієнтації збуту продукції агросектору. Це пов'язане із суттєвим розширенням зовнішніх ринків збуту для українських сільськогосподарських виробників та активізацією великих агрохолдингів, діяльність яких поширюється наразі практично на всі сектори виробництва сільськогосподарської продукції, включаючи тваринництво, рослинництво, зберігання та переробку.

Ключовою причиною таких змін відкриття для українських сільськогосподарських виробників ринків Європейського Союзу, яке відбулося в контексті реалізації положень укладених раніше євроінтеграційних угод. При цьому наслідком відкриття нових ринків стало посилення активності аграрних підприємств на зовнішніх ринках в аспекті розширення їх експортної активності. Разом з тим, попри однозначно позитивні наслідки такого зростання ділової активності та збільшення ринків збуту сільськогосподарської продукції, існує і ряд проблемних моментів, пов'язаних забезпеченням належного рівня конкурентоспроможності українських агровиробників не лише у сфері операцій із сировиною, але й у сфері переробки. Усе це потребує суттєвої оптимізації управління ризиками сільськогосподарського експорту 
задля забезпечення високої ефективності національних підприємств на зовнішніх ринках.

Аналіз останніх досліджень і публікацій, у яких започатковано вирішення даної проблеми. Проблематика забезпечення ефективності управління діяльністю сільськогосподарських виробників в процесі здійснення ними експортних операцій достатньо широко розкрита в працях таких українських дослідників даного наукового напрямку, як В. В. Россоха, Т. О. Осташко, О. М. Шпичак, О. В. Бондар, О. М. Шарапа, M. I. Пугачов, О. М. Ковінько та інші. Також варто відзначити значний вклад в дослідження специфіки проведення експортних операцій підприємств агросектору, які розкриті в працях С. В. Майстро, О. М. Могильного, В. А. Боржової, М. Д. Корінько, В. Г. Андрійчука, Є. Л. Гриня та інших вчених. Водночас, особливості сучасного етапу розвитку аграрного сектору значно залежить від впливу на нього зовнішніх ринкових факторів, які обумовлюються прискоренням темпів глобалізації, що вимагає вдосконалення підходів щодо формування ефективної експортної політики агарних підприємств.

Цілі статті. Метою статті є дослідження існуючих принципів та положень щодо забезпечення ефективності експортної діяльності сільськогосподарських виробників в Україні; визначення нових дієвих підходів, методів та інструментарію стимулювання підвищення прибутковості експортних операцій українськими аграрними підприємствами, а також розробка пропозицій, спрямованих на вдосконалення існуючих механізмів щодо забезпечення підвищення загальної ефективності експортних операцій підприємств агропромислового комплексу.

\section{Виклад основного матеріалу дослідження 3 повним обгрунтуванням отриманих наукових результатів.}

Особливості сучасного етапу функціонування сільськогосподарських підприємств експортерів відзначаються не лише підвищенням обсягів збуту аграрної продукції на зовнішні ринки і зростанням загальної прибутковості підприємств агросектору. Діяльність на нових для українських аграріїв ринках розвинутих європейських країн продемонструвала також і ряд проблем, які пов'язані з порівняно нижчим рівнем конкурентоспроможності національних підприємств на цих ринках. Головною перешкодою підвищення ефективності діяльності українських сільськогосподарських компаній в даному аспекті $\epsilon$ не надто високий рівень якості продукції, яка поставляється на експорт. I якщо ситуація з сільськогосподарською сировиною перебуває на відносно високому рівні і вона є затребуваною у європейських споживачів, то у сфері збуту продукції переробного комплексу існують відчутні проблеми. При цьому необхідно зауважити, що продукції сировинного походження, зазвичай, відзначається невисоким рівнем доданої вартості і приносить порівняно нижчий дохід, ніж товари сектору агропереробки.

Як зазначає в даному аспекті В. Россоха, «лібералізація зовнішньої торгівлі розкрила проблеми послаблення конкурентних позицій товаровиробників агропродовольчої продукції (внаслідок їх неготовності конкурувати з європейськими й американськими товарами за показниками якості), насамперед, її експортоорієнтованих видів, і посилення конкуренції між національними й іноземними суб' єктами економіки. До того ж більша частина експорту аграрної продукції має сировинний характер 3 низькою доданою вартістю, а місткість внутрішнього ринку країни обмежується багатьма чинниками специфічного спрямування розвитку аграрного бізнесу та державного регулювання галузі» [2, с. 45].

Таким чином необхідно враховувати той факт, що лише належна конкурентоспроможність продукції, що поставляється на експорт, дозволить українським аграріям посилити свої позиції на нових ринках. Разом з тим, не варто обмежуватися лише питаннями якості експортно орієнтованих аграрних виробництв. Адже значний вплив на експортні операції та загалом на процес зовнішньоекономічної діяльності українських підприємств справляє загальна їх конкурентоспроможність у 
порівнянні з іншими компаніями, що функціонують на міжнародних ринках. В даному аспекті важливу роль також відіграють ефективність системи управління підприємством, кваліфікація управлінського персоналу, підходи до налагодження системи та каналів збуту продукції, управління якістю тощо. В такому значенні більш адекватним є застосування поняття загальної конкурентоспроможності аграрних підприємств, а не обмеження проблемами конкурентоспроможності продукції. Як зауважує з даного приводу Є. Л. Гринь, «зовнішньоекономічну діяльність в агробізнесі треба спрямовувати не на імпорт будь-яких продуктів, а на створення національних виробництв за рахунок спільного інвестування на території України, з випуском конкурентоспроможної продукції, що відповідає міжнародним вимогам якості і може йти на експорт» [1, с. 173].

Отже, можна визначити, що в умовах виходу на висококонкурентні ринки українські сільськогосподарські підприємства потребують не лише підвищення якості продукції, котра спрямовується на експорт, але й, перш за все, повинні провести комплексну перебудову системи менеджменту для досягнення належного рівня ефективності, співвідносного з конкурентами.

Разом 3 тим, оцінюючи експорту активність українських сільськогосподарських підприємств, необхідно зважити на його структуру за головними товарними групами продукції агросектору (рис. 1).

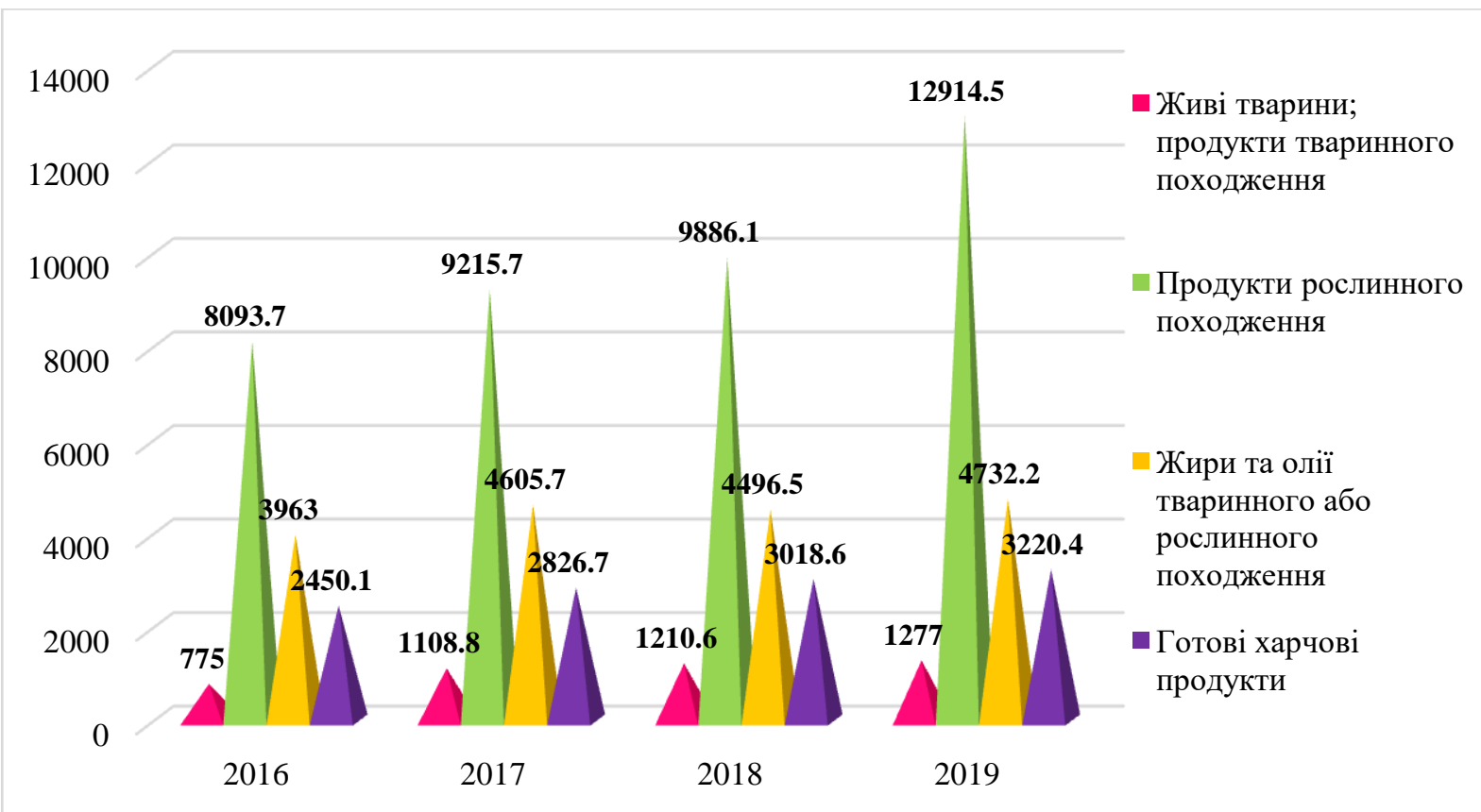

Рис. 1. Динаміка товарної структури експорту підприємств агросектору України за 2016 - 2019 рр., млн. доларів США

Джерело: [2]

Як бачимо, загальна тенденція експорту продукції сільського господарства за аналізований період показує постійне зростання його обсягів за усіма ключовими товарними групами. При цьому традиційно найбільшу частку займає продукція рослинництва, а на другій позиції знаходяться жири та олії. Обидві товарні групи фактично на 80\% являють собою сільськогосподарську сировину і продукцію ії первинної переробки. В той же час обсяг експортованих готових харчових продуктів, які $\epsilon$ найбільш рентабельними для сільськогосподарських виробників, складає лише близько 15-16\% в загальній його структурі. Оцінювати ситуацію з експортом продукції тваринного походження необхідно з врахуванням специфіки існуючих диспропорцій у цій галузі, що потребує окремого дослідження. Крім того, оскільки в загальній 
структурі дана товарна група займає найменшу частку, то в загальному не $\epsilon$ визначальною для формування тенденцій аграрного експорту України.

Крім того, необхідно зважити на поступове нарощення обсягу сировинних товарних груп в структурі українського сільськогосподарського експорту. Зокрема, за аналізований період частка продукції рослинництва зросла з 53 до 58,3\%, а частка готових харчових продуктів за цей же період несуттєво, але знизилася - 316 до 14,8\%.

Отже, можна зробити висновок, що зазначені вище проблеми, пов'язані 3 забезпеченням конкурентоспроможності підприємств агросектору насправді впливають на обсяг та структуру їх експорту. Розглянемо також структуру готових харчових продуктів, які спрямовувалися на експорт українськими підприємствами (рис. 2).

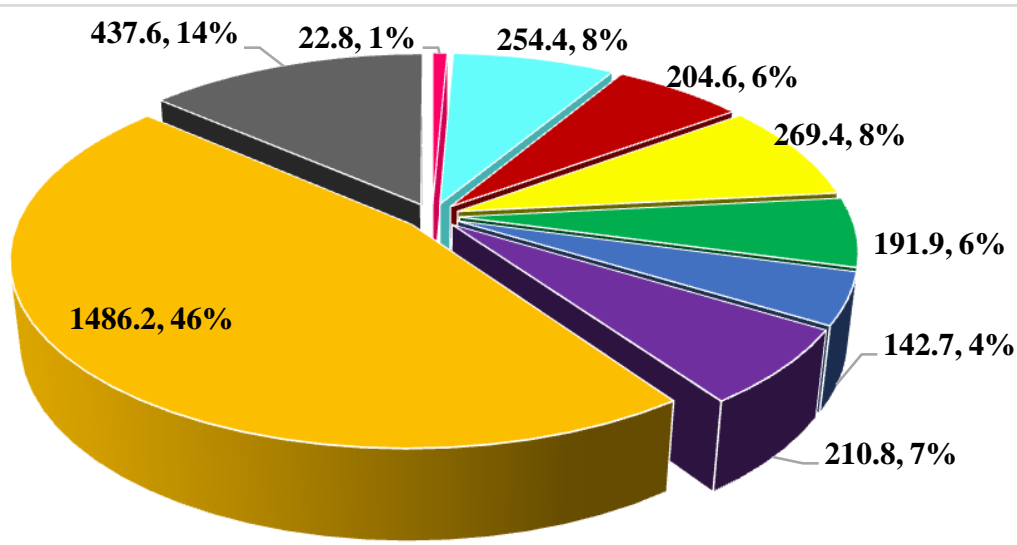

- продукти з м'яса, риби

- какао та продукти з нього

- продукти переробки овочів

- алкогольні і безалкогольні напої та оцет

- тютюн і промислові замінники тютюну

\author{
цукор і кондитерські вироби з цукру \\ готові продукти із зерна \\ - різні харчові продукти \\ - залишки і відходи харчової промисловості
}

Рис. 2. Структура експорту готових харчових продуктів в Україні у 2019 р., млн. доларів США

Джерело: [2]

Як бачимо, навіть структура експорту готових харчових продуктів українських підприємств на 46\% складається з низькорентабельних залишків та відходів переробки харчових продуктів та сировини. Усе це дає підстави стверджувати про невисокий рівень конкурентоспроможності підприємств агросектору України на зовнішніх ринках, незважаючи на сприятливі умови для розширення їх діяльності.

Висновки. Отже, можна стверджувати, що забезпечення ефективності функціонування сільськогосподарських підприємств в аспекті розширення обсягів їх експортної діяльності нерозривно пов'язане з необхідністю підвищення загального рівня їх конкурентоспроможності. Як показують результати аналізу, вітчизняні аграрні виробники наразі працюють, головним чином, у сфері експорту сировинних продуктів сільського господарства і недостатньо активно просувають товарну групу готових харчових продуктів для продажу на зовнішніх ринках. Відтак, лише загальне підвищення якості продукції, системи управління та менеджменту вітчизняних агровиробників сприятиме підвищенню ї конкурентоспроможності i дозволить активізувати зусилля на збільшенні частки ринку 3 вищим рівнем рентабельності продажів готової продукції сектору агропереробки.

\section{Список бібліографічного опису:}

1. Гринь Є. Л. Політика розвитку агробізнесу в Україні в напрямі захисту внутрішнього продовольчого ринку. Актуальні проблеми державного управління. 2009. № 1 (35). С. 171-178.

2. Державна служба статистики України. URL: http://www.ukrstat.gov.ua (дата звернення 8.05.2021р.). 
3. Россоха В., Шарапа О. Експортний потенціал аграрних підприємств. Зовнішня торгівля: економіка, фінанси, право. 2016. № 4. С. 44-63.

\section{Reference:}

1. Hryn', E. L. Polityka rozvytku agrobiznesu $v$ Ukrayini $\mathrm{v}$ napriami zahystu vnutrishniogo prodovolchogo rynku [Agribusiness development policy in Ukraine in the direction of protecting the domestic food market]. Aktualni problem derzhavnogo upravlinnia - Actual problems of public administration. 2009. Vol. 1(35). Pp. 171-178. [in Ukrainian].

2. State Statistics Service of Ukraine. Retrieved from: http://www.ukrstat.gov.ua (accessed on 8 May 2021).

3. Rossokha, V., Sharapa, O. Eksportnyi potentsial agrarnykh pidpryiemstv [Export potential of agricultural enterprises]. Zovnishnia torhivlia: ekonomika, finansy, pravo - Foreign trade: economics, finance, law. 2016. Vol. 4. Pp. 44-63. [in Ukrainian].

Дата подання публікації 08.05.2021p.

\section{УДК 657}

Камінська I.M., к.е.н., доцент Kaminska I. Candidate of Economic Sciences, Associate Professor https://orcid.org/0000-0001-6181-7522

Ковальчук Н.В., к.е.н., доцент Kovalchuk N. Candidate of Economic Sciences, Associate Professor https://orcid.org/0000-0001-7621-5882

Демидович А.С., аспірант Demydovych A. Postgraduate Student

Горчинська I.П., бакалавр Horchynska I. Bachelor

\section{ТЕОРЕТИКО-МЕТОДИЧНІ ПІДХОДИ ДО АНАЛІЗУ ЕФЕКТИВНОСТІ ДІЯЛЬНОСТІ ПІДПРИЕМСТВА}

\section{Луцький національний технічний університет}

У статті здійснено системне дослідження теоретичних і методичних підходів до аналізу ефективності діяльності підприємства.

На основі аналізу сучасних теоретичних підходів вчених-економістів до розуміння сутності категорії «ефективність діяльності підприємства» виокремлено такі підходи до ії трактування: економічний підхід; оціночний підхід; затратний підхід; цільовий підхід; фінансовий підхід; комплексний підхід. Трактуючи ефективність діяльності підприємства варто враховувати усі підходи вчених, що дозволить розглядати цю категорію у найширшому значенні.

Базуючись на проведеному дослідженні, доведено, що ефективність діяльності підприємства характеризує його здатність досягати позитивні кількісні та якісні результати від провадження підприємницької діяльності й відповідно досягати визначених цілей при раціональному використані усіх наявних ресурсів.

Встановлено, що категорії «ефективність», «продуктивність», «результативність», «інтенсивність», «економічність», «прибутковість», «доходність», «дієвість», «раціональність» $\epsilon$ самостійними й відмінними, що водночас виражають сукупність параметрів комплексної категорії «ефективність діяльності підприємства».

У статті обгрунтовано сутність та визначено цілі аналізу ефективності діяльності підприємства. Наведено принципи аналізу ефективності діяльності підприємства. Сформовано алгоритм й визначено етапи аналізу ефективності діяльності підприємства.

На основі розгляду сучасних методичних підходів до аналізу ефективності діяльності підприємства встановлено, що відсутній єдиний і універсальний методичний підхід до їі аналізу.

У статті розглянуто зміст і особливості основних методик аналізу ефективності діяльності підприємства. Встановлено, що комплексний, деталізований та усесторонній аналіз ефективності діяльності підприємства повинен охоплювати різноманітні методи та прийоми аналізу.

Резюмуючи методичні підходи науковців до аналізу ефективності діяльності підприємства, у статті систематизовано за групами узагальнюючі і часткові показники. 
Доведено, що аналіз ефективності діяльності підприємства $є$ важливим i необхідним інструментом визначення поточного іiі рівня, вивчення резервів підвищення ефективності діяльності суб’єкта господарювання й формування конкретного і адекватного інструментарію нарощення його кінцевих 